\title{
O SOCIÓLOGO DAS ORGANIZAÇÕES: FERNANDO C. PRESTES MOTTA
}

\author{
Luiz Carlos Bresser-Pereira \\ FGV-EAESP
}

Fernando C. Prestes Motta é um dos mais ilustres professores desta casa e um dos intelectuais mais significativos com que o país conta alguém que vem procurando sistematicamente compreender o Brasil, suas organizações e a cultura que as ilumina. Declaro-me desde já suspeito. Sou seu cunhado. Fui seu professor. Trabalhamos juntos em alguns momentos. Sou seu amigo. Não obstante, espero poder ser razoavelmente objetivo em que vou dizer. Jamais plenamente, porque a pretensão à objetividade é o apanágio dos tolos e dos arrogantes.

A primeira frase com que abro minha intervenção nesta homenagem é auto-evidente. Fernando C. Prestes Motta é reconhecido por colegas e alunos como um homem de grande cultura, como um notável professor de Administração, como o principal teórico das organizações no Brasil. A homenagem que hoje ele está recebendo é uma demonstração desse fato. Já a segunda afirmação a de que Prestes Motta tem uma contribuição importante para o entendimento da sociedade moderna, da sociedade das organizações e da natureza da sociedade brasileira nesse quadro mais amplo - será o objeto de minha breve comunicação.

Seus artigos e livros sobre a teoria das organizações - um dos quais em colaboração comigo (Introdução à organização burocrática) - já seriam suficientes para sustentar minha tese $^{1}$. Também devem ser conhecidos os trabalhos que vem realizando na área da cultura brasileira e das organizações. Quero, entretanto, discutir aqui dois outros tipos menos conhecidos de contribuição, que o tornam um sociólogo ou, mais amplamente, um cientista social eminente, com vôo próprio.

Sociólogo? Sem dúvida. Um sociólogo político que honra a sociologia brasileira, embora não tenha um diploma em Sociologia (é doutor e livre-docente pela USP em Educação), não ensine sociologia, nem seja usualmente considerado por seus pares como sociólogo - o mundo acadêmico é sempre caracterizado pelos guetos.

Como sociólogo político, Prestes Motta escreveu, inicialmente, um livro importante sobre a transição democrática que então se iniciava -"Empresários e hegemonia política (1979). Em seguida, volta-se para uma questão sociológica e política mais geral, Burocracia e autogestão - a proposta de Proudhon (1981). É sua tese de doutorado. É uma fascinante análise do pensamento de Proudhon sob a ótica da autogestão, questão central no pensamento do grande socialista francês. Prestes Motta, Maurício
Tragtenberg e eu fazíamos então nossa crítica da tecnoburocracia e das organizações burocráticas, combinando conceitos marxistas e weberianos, e víamos na autogestão a saída possível. De nós três, que discutíamos o tema apaixonadamente, foi ele quem aprofundou a análise desse tema. Prestes Motta criticou a heterogestão tecnoburocrática - palavra que só tem sentido em oposição à autogestão - de forma incisiva. Diz ele, em certo momento: "Da mesma forma que a heterogestão naturalizou a função diretiva do capital sobre o trabalho, ela agora naturaliza a função diretiva do saber sobre o não saber" (1981). Na mesma área, publicou logo após um pequeno livro, Participação e co-gestão (1982), em que analisava a possibilidade de a co-gestão ser um caminho para a autogestão, na medida em que os trabalhadores ganhassem gradualmente consciência política e competência técnica. E concluía, depois de analisar a co-gestão em diversos países, que "a grande oposição que a co-gestão encontrou e encontra entre empregadores alemães parece já ser um bom indício de que, se ela funciona no capitalismo avançado como uma forma de reprodução do poder do capital, ela também representa uma conquista não desprezível da classe trabalhadora" (1982, p. 74). 
Uns poucos anos mais tarde, em 1986, Prestes Motta amplia sua crítica da burocracia, com Organização e poder, sua tese de livre-docência na USP, provavelmente seu livro mais importante. Seu tema é a burocracia enquanto forma despótica de dominação. Dominação não apenas política, no plano do estado; dominação também ao nível da sociedade, nos termos complexos desenvolvidos por Foucault, e sempre ao nível das organizações burocráticas - da grande empresa, da escola.

A visão de Prestes Motta da burocracia é eminentemente crítica. Crítica do capitalismo tecnoburocrático até hoje dominante, no qual a tecnoburocracia divide o poder com a classe capitalista. Crítica do estatismo soviético, em que a tecnoburocracia torna-se a única classe dominante. E crítica da própria teoria das organizações, que, se por um lado é uma poderosa contribuição da sociologia à compreensão do mundo moderno, é também carregada de ideologia. Em suas palavras, "enquanto teoria das organizações convencional, oculta o projeto hegemônico dessa classe e nega sua própria condição de classe" (1986).

Depois desse livro, porém, Prestes Motta reduz seu interesse pela sociologia política geral. Volta-se, agora, para a cultura organizacional e para as relações entre a antropologia, a psicanálise e a organização. São temas teóricos que ele analisa tendo em vista o Brasil. Segundo ele, a grande questão se refere ao modo pelo qual o comportamento das organizações varia culturalmente. A partir dessa observação, Prestes Motta busca entender a identidade cultural brasileira a partir dos grandes autores que pensaram o tema.

Observa ele, nesse campo, que "é difícil falar em revolução burguesa no Brasil. A dominação burguesa e tecnocrática em nosso país segue um padrão de dupla articulação, que dificulta o uso dessa expressão... Uma classe dominante com traços de burguesia e tecnocracia cosmopolitas apresenta valores e comportamentos de pretensa aristocracia de senhores de engenho" (1997). Não poderia eu concordar mais com ele. Em alguns momentos, as elites brasileiras brilharam. Esse foi o caso das elites cafeeiras do Oeste paulista, que iniciaram a revolução capitalista brasileira. Foi também o dos empresários industriais e o dos técnicos governamentais reunidos por Getúlio Vargas, que a partir dos anos 1930 impulsionaram de forma decisiva a industrialização e a revolução nacional brasileira. Mas estes foram momentos excepcionais. Nos últimos 20 anos, o que temos visto é a incapacidade de nossas elites de pensar com a própria cabeça, ao invés de se pautar pelas idéias vindas do Norte, e superar a instabilidade macroeconômica que mantém o país semiestagnado há 22 anos.

Mas, se Prestes Motta busca sempre compreender nosso país, pensálo segundo nossos próprios critérios, nunca deixou de se preocupar com o mais geral. E esse mais geral ele foi procurar, nos últimos anos, em Freud. Com a psicanálise, e principalmente as obras sociológicas nas quais Freud desenvolveu os pressupostos universais da cultura humana, Prestes Motta procura entender as organizações e, mais amplamente, a sociedade em que vivemos. Nesse ponto, a observação que mais me impressionou diz respeito ao vínculo social. Diz-nos ele que o princípio que está na base do vínculo social, servindo de fundamento de todas as organizações, é ao mesmo tempo aquilo que pode conduzir à sua dissolução, ou mesmo à sua destruição. E completa: "toda instituição social parte de indivíduos que são iguais, mas que se sentem oprimidos ou minoritários, e que buscam a concepção de um projeto que os torne sujeitos e irmãos" (2000).

Sem dúvida, somos iguais. Mas será que somos iguais por natureza ou, segundo Freud, porque conquistamos essa igualdade? Ou, mais precisamente, porque a estamos conquistando, já que os pobres ainda não conquistaram. Igualdade de direitos, não de talentos ou capacidades, igualdade política, portanto, sem a qual a liberdade não faz sentido. Prestes Motta não responde a essas perguntas. Mais pessimista, ele segue com Freud e afirma que o homem, ao se associar, constitui a massa, "uma reunião de indivíduos que substituíram seu ideal do ego por um único e mesmo objeto". Assim, "a formação da massa pode ser entendida como um jogo de investimentos libidinais, não havendo nada parecido como o 'instinto gregário'. O homem não é um animal de rebanho, mas um animal de horda. A horda primitiva é reeditada na multidão" (2000).

Talvez Fernando tenha razão. E eu sei que um dia de homenagem não é um dia de debates. Mas aqui não fala o irmão mais velho, nem o professor, fala o amigo cuja paixão particular é o debate público. Fala para dizer que essa visão da humanidade é pessimista em excesso. Sem dúvida somos egoístas, voltados para nossas paixões e nossos interesses, mas somos também, ainda que em menor grau, capazes da generosidade e da cooperação. Se não fosse assim, seria difícil compreender por que as sociedades aprendem a premiar a virtude e o comportamento republicano; por que, pouco a pouco, constroem as instituições necessárias para a vida civilizada. 
Hoje, Fernando, você não tem o direito de resposta, ainda que estejamos em uma democracia. Hoje não é dia de debate, é dia de homenagem, e eu me junto a todos os presentes para homenageá-lo e também à sua mulher, Cristina, que é seu segredo e sua força. Tenho a honra de ser seu colega, tenho a alegria de ser seu amigo.

\section{Notas}

Intervenção na homenagem prestada por professores da FGV-EAESP a Fernando Cláudio Prestes Motta. São Paulo, 3 de setembro de 2002.

\section{Luiz Carlos Bresser-Pereira}

Professor do departamento de Planejamento e Análises Econômicas da FGV-EAESP.

E-mail: bresser@fgvsp.br 